Proceedings

\title{
Evaluation of Antioxidant Properties of Choloroform Extract of Chasmanthera dependens Roots ${ }^{+}$
}

\author{
Augustine Chidi *, Nwanelo Odirachukwu, Tabansi Chukwuemeka, Onoh Amarachukwu \\ Anichebe Remigus, Okosis Anayo and Anosike Chioma \\ Department of Biochemistry, University of Nigeria, Nsukka enugu State, Nigeria; \\ valentine.nwanelo@unn.edu.ng (N.O.); emmanuel.tabansi@unn.edu.ng (T.C.); \\ amarachukwu.onoh.188209@unn.edu.ng (O.A.); anichebe.remigus@gmail.com (A.R.); \\ okosisi.anayo@gmail.com (O.A.) and chioma.anosike@unn.edu.ng (A.C.) \\ * Correspondence: chidi.madueke@unn.edu.ng \\ + Presented at the 1st International e-Conference on Antioxidants in Health and Disease, 01-15 December \\ 2020; Available online: https://cahd2020.sciforum.net/.
}

Published: 30 November 2020

\begin{abstract}
Chasmanthera dependens is a medicinal plant with wide application in African traditional medicine for the management of several pathologies. We report the antioxidant properties of the chloroform extract of $C$. Dependens root (CECDR) as to auspiciously provide scientific information that could explain some of the reported roles of the plant in human diseases. In vitro studies assayed for 1, 1-diphenyl2-picrylhydrazyl (DPPH) scavenging, hydrogen peroxide scavenging, ferric reducing antioxidant power (FRAP), and total antioxidant capacity (TAC). DPPH radical scavenging activity was concentration dependent with an EC 50 of $647.67 \mu \mathrm{g} / \mathrm{mL}$. CECDR showed a positive hydrogen peroxide scavenging with $\mathrm{EC}_{50}$ of $57.78 \pm 2.93 \mu \mathrm{g} / \mathrm{mL}$ relative to ascorbic acid standard (EC50: $90.06 \mu \mathrm{g} / \mathrm{mL}$ ). The ferric reducing antioxidant power of CECDR at $15.6 \mu \mathrm{g} / \mathrm{mL}$ was $21.18 \pm 0.15 \mu \mathrm{g}$ gallic acid equivalents (GAE) while that of $1000 \mu \mathrm{g} / \mathrm{mL}$ was $0.03 \pm 0.00 \mu \mathrm{g}$ GAE. CECDR at a concentration $15.6 \mu \mathrm{g} / \mathrm{mL}$ showed a TAC of $15.22 \pm 7.81 \mu \mathrm{g}$ ascorbic acid equivalents (AAE) while that of $1000 \mu \mathrm{g} / \mathrm{mL}$ was $0.03 \pm 0.00 \mu \mathrm{g}$ AAE. In vivo analysis of CCl4-induced wistar rats showed a significant increase $(p<0.05)$ in the concentrations of superoxide dismutase, catalase and glutathione peroxidase in the treated groups relative to the untreated control. In conclusion the observed antioxidant properties of CECDR could be attributed to its rich phytochemical repertoire.
\end{abstract}

Keywords: free radical; antioxidant; Chasmanthera dependens; ascorbic acid; CCL4

\section{Introduction}

In Africa, plants are used widely for the treatment of various ailments such as, malaria, diabetes, veneral diseases, hypertension and different infectious diseases even though little is known about their mode of action (Ogunlesi, et al., 2008; Shrikant et al., 2012; Monon et al., 2013). The rich phytochemical constituents of the extracts of these plants are believed to be largely responsible for their observed therapeutic effects some of which are anti-inflammatory, antioxidant and antiplasmodial.

Many diseases are not unconnected to oxidative stress caused by the activities of reactive oxygen species such as hydroxyl free radicals, superoxide anion, hydrogen peroxide and lipid peroxyl (Vijaya et al., 2010). Oxidative stress leads to lipid peroxidation, protein and DNA damage and occurs when the body's defence mechanism responsible for antioxidant activities is overwhelmed by free radicals (both endogenous and exogenous) (Chun-Weng, 2011). This has inspired diverse studies searching 
The 1st International Electronic Conference on Antioxidants in Health and Disease, 1-15 December 2020

for medicinal plants with antioxidant activities, some of which have been identified like Carissa edulis, Acacia ataxacantha, Cucurbita maxima, Peganum harmala and Curcuma caesia (Amoussa et al., 2015; Reenu et al., 2015; Kanwal et al., 2016; Fanta et al., 2019; Ozioko et al., 2020). Lateef et al. (2016) demonstrated the antioxidant activity of silver nanoparticles synthesized using bio resources of which Cola nitida, a medicinal plant was a part.

Chasmanthera dependens known locally as "ato" by the Yoruba indigenous group of Nigeria is a shrub found mostly in savannah and forest margin of many Afrcan countries like Sierra Leone, Zimbabwe and Nigeria (Borokini and Lawal, 2014; UTPD, 2014). In Nigeria, the stem of $C$ dependens together with other plants is used in the treatment of convulsions and epilepsiy, while in congo, its root sap is applied on wounds to stop bleeding (Mosango, 2008; Monon et al., 2013; Wahab, 2015). C. dependens has been shown from previous studies, to possess analgesic and anti-inflammatory (Onabanjo et al., 1991; Kola-Mustapha, et al., 2020), antiulcerogenic (Tijani et al., 2018), fertilityenhancing (Quadri, \& Yakubu, 2017), hepatocurative (Ogbozor and Anosike, 2020), and nephroprotective (Abiola et al., 2020) effects.

However, this study seeks to evaluate the in vivo and in vitro free radical scavenging of the chloroform extract of Chasmanthera dependens root.

\section{Materials and Methods}

\subsection{Plant Materials}

Fresh roots of Chasmanthera dependens $(6 \mathrm{~kg})$ were obtained from Orba Local Government Area of Enugu state Nigeria. Mr Ozioko Alfred a taxonomist at the Bioresources Development and Conservation Program Research Centre, Nsukka identified the plant roots. Voucher specimen was deposited in the herbarium unit of the Department of Botany, University of Nigeria, Nsukka for reference purposes.

\subsection{Study Animals}

Eighteen albino Wistar mice were used for the acute toxicity studies, twenty-four adult albino Wistar female rats weighing between 143 to $210 \mathrm{~g}$ for invivo antioxidant study. The rats where obtained from the animal unit of the Faculty of Zoology and Environmental Biology, University of Nigeria, Nsukka. They were acclimatized for a week under standard laboratory conditions at the Animal Farm of the Department of Biochemistry.

\subsection{Chemicals and Reagents}

Analytical grade chemicals were used for the study.

\subsection{Extraction Procedure}

The roots of Chasmanthera dependens plant were harvested and dried for 2 weeks under room temperature $\left(25^{\circ} \mathrm{C}\right.$ to $\left.45^{\circ} \mathrm{C}\right)$ and was ground into powder.

The dried roots of Chasmanthera dependens were pulverized into a coarse form using a mechanical grinder. Powdered sample was soaked in 50\% chloroform in a $3000 \mathrm{~mL}$ conical flask and the top sealed with foil and taped to prevent evaporation. The system was shook vigorously and then allowed to stand for $48 \mathrm{~h}$ with occasional stirring. The mixture was thereafter filtered using a mesh and then a Whatman No. 1 filter paper. The process was repeated twice and the resulting chloroform filtrate concentrated using a rotary evaporator at $45^{\circ} \mathrm{C}$ to obtain the crude extract. A known weight of the dry extract was determined, then stored in a refrigerator at $4{ }^{\circ} \mathrm{C}$ under antiseptic conditions until needed.

\subsection{Acute Toxicity Study of CECDR}


The 1st International Electronic Conference on Antioxidants in Health and Disease, 1-15 December 2020

Using the method described by Lorke (1983), the acute toxicity and lethality (LD50) of the chloroform extract of $C$. dependens root in mice $(n=18)$ was estimated. In stage one of the test, animals received oral administration of 10,100 and $1000 \mathrm{mg} / \mathrm{kg}$ b.w of extract $(n=3)$ and observed for 24 hours for mortality. The test proceeded to the second stage where the mice $(n=3)$ received 1600, 2900 and $5000 \mathrm{mg} / \mathrm{kg}$ doses of CECDR. They were also observed for $24 \mathrm{~h}$ for signs of behavioural changes or mortality.

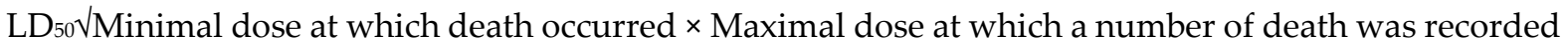

\subsubsection{Qualitative and Quantitative Phytochemical Analysis of CECDR}

Phytochemical analysis were carried out to establish the presence of plant secondary metabolites in CECDR using the methods outlined by Wallis (1967), Harborne (1973), Swain (1979), Trease and Evans, (1983), Brunner, (1984) and Sofowora, (1986).

\subsubsection{Quantitative Diphenylpicryl Hydrazyl (DPPH) Radical Scavenging Assay}

This was determined using a slight modification of the method of Gyamfi et al. (1999). CECDR $(1 \mathrm{~mL})$ at different concentration was diluted 2-fold $(1.25-160 \mu \mathrm{g} / \mathrm{mL})$. Methanol $(80 \%)$ was mixed with $0.5 \mathrm{~mL}$ of $0.082 \mathrm{~mm} \mathrm{DPPH}$ in methanol, shaken vigorously and then allowed to stand in the dark for $25 \mathrm{~min}$ at room temperature. 1 mole of $0.076 \mathrm{~mm}$ of DPPH in methanol was used as the negative control and L-ascorbic acid as the positive control. The absorbance of the assay was measured at $517 \mathrm{~nm}$ and DPPH radical scavenging activity calculated using the equation:

$$
\frac{\mathrm{A}_{0}}{\mathrm{~A}_{0}} \mathrm{X} \frac{\mathrm{A} 100}{1}=\% \text { Scavenging activity }
$$

$\mathrm{A}_{0}=$ absorbance of control

$\mathrm{A}_{\mathrm{s}}=$ absorbance of CECDR

\subsubsection{Ferric Reducing Antioxidant Power (FRAP) Assay}

The ferric reducing power of CECDR was determined as described by Salireen et al. (2010). This assay is based on the reduction of $\mathrm{Fe}^{3+}$ to $\mathrm{Fe}^{2+}$ by CECDR in acidic medium (Benzie, 1996).

\subsubsection{Hydrogen Peroxide $\left(\mathrm{H}_{2} \mathrm{O}_{2}\right)$ Assay}

The hydrogen peroxide scavenging ability of CECDR was determined according to the method of Ruth et al. (1989).

\subsubsection{Total Antioxidant Capacity (TAC) Assay}

The total antioxidant capacity is carried out by the phosphomolybdate assay system (Garrat 1964) and is based on the reduction of Mo (VI) to Mo (V) by CECDR. The antioxidant capacity (TAC) is expressed as equivalents of ascorbic acid and calculated using the equation:

$$
\mathrm{TAC}(\%)+\mathrm{X} \longrightarrow \mathrm{A}_{0}-\mathrm{A} 100
$$

$\mathrm{A}_{0}=$ absorbance of control

$\mathrm{A}_{\mathrm{s}}=$ absorbance of CECDR

\subsubsection{Evaluation of Endogenous Antioxidant}

Antioxidant enzymes; superoxide dismutase (SOD), catalase (CAT), and glutathione peroxidase (GPx), and lipid peroxidation marker; malondialdehyde (MDA) were determined using the methods of Mocorel and Fridwich (1969), Barman et al. (1981), Paglia and Valentine (1967), and Satoh (1976) respectively from the serum. 
The 1st International Electronic Conference on Antioxidants in Health and Disease, 1-15 December 2020

2.6. Experimental Animals

Twenty-four (24) Wistar albino female rats were acclamatized for 7 days and then housed in 6 separate cages consisting of 4 rats each. A modification of the method of Karthikeyan and Deepa (2010) was used. The route of administration of $\mathrm{CCl}_{4}$ was by intraperitoneal injection which was given every seventy- two (72) hours for ten (10) days. Group 1 = Normal control (administered with normal saline); Group 2 = Experimental control $\left(\mathrm{CCl}_{4}\right.$ induced and untreated); Group $3=$ Low dose $\left(\mathrm{CCl}_{4}\right.$ administered and treated with $200 \mathrm{mg} / \mathrm{kg}$ body weight of CECDR); Group $4=\mathrm{Mid}_{-\mathrm{dose}}\left(\mathrm{CCl}_{4}\right.$ administered and treated with $400 \mathrm{mg} / \mathrm{kg}$ body weight of CECDR); Group $5=$ High dose $\left(\mathrm{CCl}_{4}\right.$ administered and treated with $600 \mathrm{mg} / \mathrm{kg}$ body weight of CECDR); Group6 = Standard control $\left(\mathrm{CCl}_{4}\right.$ administered and treated with $200 \mathrm{mg} / \mathrm{kg}$ body weight of Silymarin).

\subsection{Statistical Analysis}

Data obtained from this study was analysed using IBM Statistical Product and Service Solution (version 20) and the result expressed as mean \pm standard deviation.

\section{Results}

\subsection{Acute Toxicity and Lethality Study of CECDR}

There was no toxicity or lethality observed in the extract up to $5000 \mathrm{mg} / \mathrm{kg}$ body weight. This suggests that the LD50 of CECDR is above $5000 \mathrm{mg} / \mathrm{kg}$ body weight.

\subsection{Qualitative Phytochemical Analysis of Chloroform Extract of Chasmanthera dependens}

The qualitative phytochemical analysis showed an abundance of alkaloids, flavonoids, and steroids in followed by moderate quantities of tannins, phenolics, carbohydrates, and terpenes. Reducing sugar and saponins was detected in low concentration while glycoside was undetected (Table 1).

Table 1. Qualitative phytochemicals of CECDR.

\begin{tabular}{cc}
\hline Constituents & Relative Abundance \\
\hline Alkaloids & +++ \\
Phenolics & ++ \\
Saponins & $\mathrm{ND}$ \\
Tanins & ++ \\
Carbohydrate & ++ \\
Flavonoids & +++ \\
Steroids & +++ \\
Glycosides & $\mathrm{ND}$ \\
Terpenoids & ++ \\
Reducing sugar & + \\
\hline
\end{tabular}

Key: $+++=$ phytochemical present in high concentration; $++=$ Present in moderate concentration; $+=$ Present in small concentration, ND $=$ Not detected.

\subsection{Quantitative Phytochemical Analysis of CECDR}

In the quantitative analysis of CECDR, phenolics (4907.25 \pm 75.33$)$ were found to have the highest concentration. It also gave a high yield of alkaloids $(1975 \pm 68.84)$, carbohydrates $(449.64 \pm 59.30)$, flavonoids $(319.79 \pm 98.93)$ and terpenes $(674.51 \pm 46.18)$ but reducing sugar $(80.8 \pm 36.1911 .44)$ tannins $(22.47 \pm 11.44)$ and steroids $(9.25 \pm 0.14)$ where found in lower concentration (Table 2$)$.

Table 2. The quantitative phytochemical analysis of CECDR. 
The 1st International Electronic Conference on Antioxidants in Health and Disease, 1-15 December 2020

\begin{tabular}{cc}
\hline Phytochemical Constituents & Bioavailability $(\mathbf{m g})$ \\
\hline Phenolics & $4907.25 \pm 75.33$ \\
Alkaloids & $1975 \pm 68.84$ \\
Carbohydrates & $449.64 \pm 59.30$ \\
Flavonoids & $319.79 \pm 98.93$ \\
Terpenes & $674.51 \pm 46.18$ \\
Reducing sugar & $80.8 \pm 36.19$ \\
Saponins & - \\
Tannins & $22.47 \pm 11.44$ \\
Steroids & $4.55 \pm 0.32$ \\
\hline Results from the quantitative analysis are \\
expressed in means \pm SD of triplicate \\
determinations $(n=10)$ & \\
\hline
\end{tabular}

\subsection{Effect of CECDR on DPPH Radical Scavenging Activity}

Figure 1 shows the quantitative DPPH analysis and revealed DPPH radical scavenging activity of CECDR. The percentage inhibition was concentration dependent with an effective concentration (EC50) of $-646.67 \mu \mathrm{g} / \mathrm{mL}$ compared to the ascorbic acid standard with $\mathrm{EC}_{50}$ of $-10.58 \mu \mathrm{g} / \mathrm{mL}$. The percentage inhibition against concentration showed a statistically positive correlation $(p<0.05)\left(\mathrm{R}^{2}\right)$ correlation of $0.9548 . n=3$.

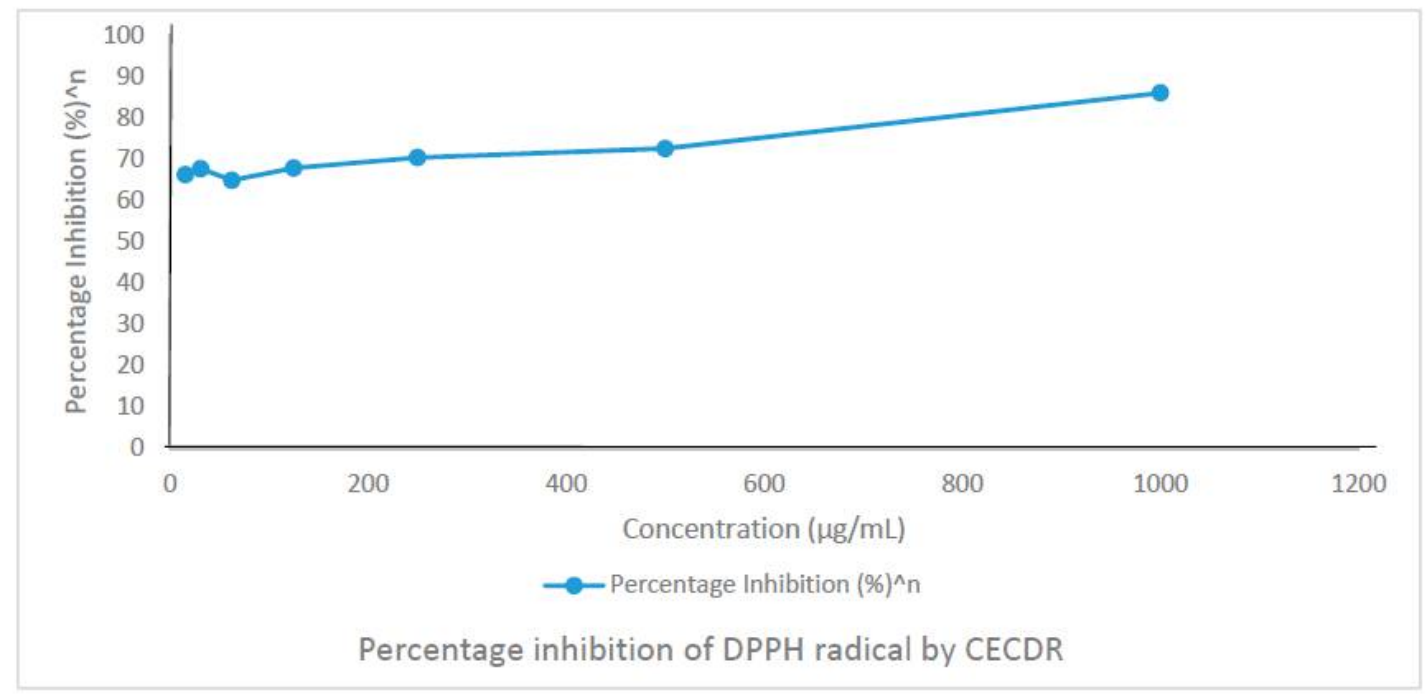

Figure 1. Percentage inhibition of DPPH radical by CECDR.

\subsection{Effect of CECDR on Hydrogen Peroxide $\left(\mathrm{H}_{2} \mathrm{O}_{2}\right)$}

The $\mathrm{H}_{2} \mathrm{O}_{2}$ scavenging activity of the chloroform extract of Chasmanthera dependens is shown in Figure 2 below. (Figure 2). The $\mathrm{EC}_{50}$ was found to be $58.78 \pm 2.93 \mu \mathrm{g} / \mathrm{mL}$. 
The 1st International Electronic Conference on Antioxidants in Health and Disease, 1-15 December 2020

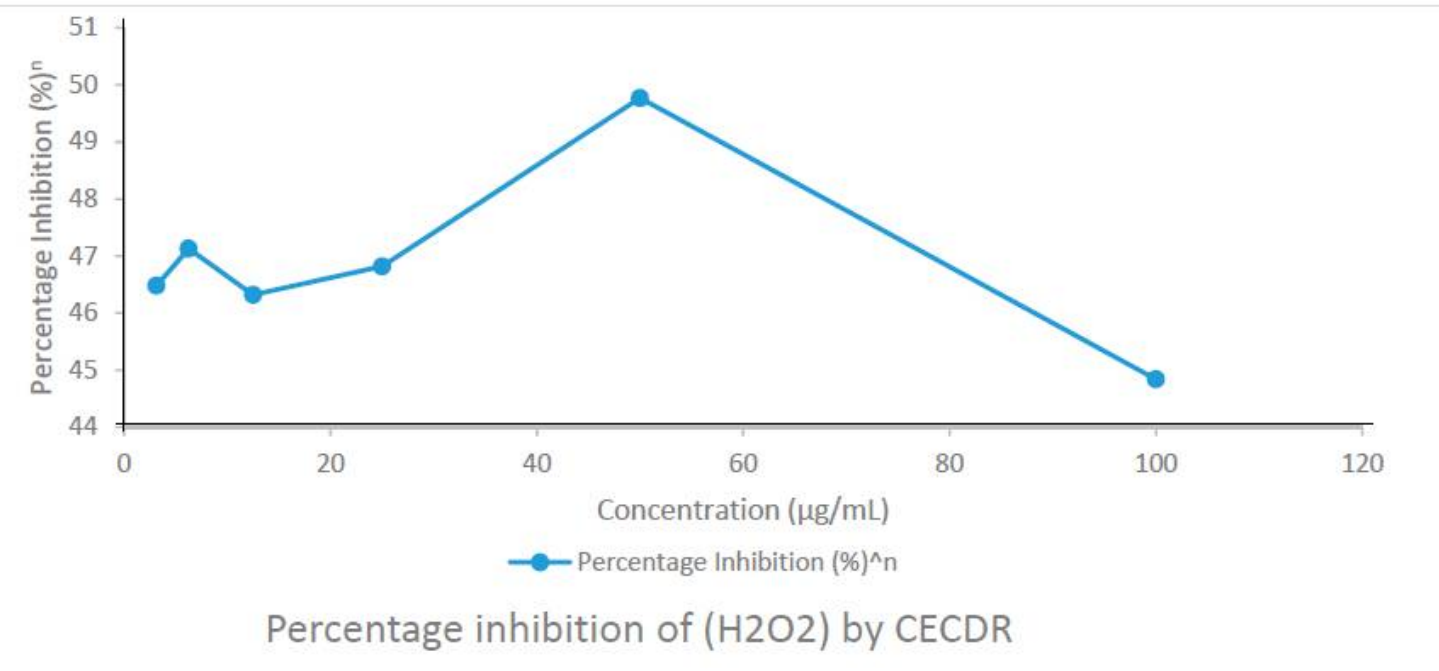

Figure 2. Percentage inhibition of $\left(\mathrm{H}_{2} \mathrm{O}_{2}\right)$ by CECDR.

3.6. Effect of Chloroform Extract of C. dependens on Ferric Reducing Antioxidant Power (FRAP)

The Ferric Reducing Antioxidant Power (FRAP) of CECDR was concentration dependent. 15.6 $\mu \mathrm{g} / \mathrm{mL}$ of CECDR showed Ferric Reducing Antioxidant Power of $21.18 \pm 0.15 \mu \mathrm{g}$ GAE while that of $1000 \mu \mathrm{g} / \mathrm{mL}$ showed FRAP of $0.03 \pm 0.00 \mu \mathrm{g}$ GAE.

Table 3. Ferric Reducing Antioxidant Power (FRAP) of CECDR.

\begin{tabular}{cc}
\hline Concentration $(\mu \mathrm{g} / \mathrm{mL})$ & Ferric Reducing Antioxidant Power (FRAP) $(\boldsymbol{\mu g}$ GAE) \\
\hline 15.6 & $21.18 \pm 0.15$ \\
31.1 & $0.72 \pm 0.06$ \\
62.5 & $0.37 \pm 0.03$ \\
125 & $0.19 \pm 0.01$ \\
250 & $0.11 \pm 0.00$ \\
500 & $0.05 \pm 0.00$ \\
1000 & $0.03 \pm 0.00$ \\
\hline
\end{tabular}

3.7. Effect of Chloroform Extract of Chasmanthera dependens on Total Antioxidant Capacity (TAC)

The Total Antioxidant Capacity (TAC) of the chloroform extract of $C$. dependens showed a concentration dependent antioxidant activity. The concentration $15.6 \mu \mathrm{g} / \mathrm{mL}$ showed a TAC of 15.22 $\pm 7.81 \mu \mathrm{g}$ AAE while that of $1000 \mu \mathrm{g} / \mathrm{mL}$ showed TAC of $0.03 \pm 0.00 \mu \mathrm{g}$ AAE.

Table 4. Total Antioxidant Capacity (TAC) of CECDR.

\begin{tabular}{cc}
\hline Concentration $(\boldsymbol{\mu g} / \mathbf{m L})$ & Total Antioxidant Capacity (TAC) $(\mu \mathrm{g}$ AAE) \\
\hline 15.6 & $15.22 \pm 7.81$ \\
31.1 & $17.71 \pm 7.35$ \\
62.5 & $7.83 \pm 3.70$ \\
125 & $3.82 \pm 0.74$ \\
250 & $3.06 \pm 0.33$ \\
500 & $2.40 \pm 0.13$ \\
1000 & $1.68 \pm 0.02$ \\
\hline
\end{tabular}

3.8. Result of the Biochemical Analysis 
The 1st International Electronic Conference on Antioxidants in Health and Disease, 1-15 December 2020

The endogenous antioxidants were evaluated as shown below.

\subsubsection{Catalase (CAT) Activity of Rats Administered with CECDR}

There is a significant $(p<0.05)$ decrease in the mean concentration of catalase in the experimental control (group 2) compared with that of normal control (group 1) whereas treatment with $C$. dependens showed significant $(p<0.05)$ increase in the catalase activity test groups (groups 3, 4 and $5)$ as well as treatment with the standard drug, silymarin in the standard control.

\subsubsection{Superoxide Dismutase (SOD) Activity of Rats Administered with CECDR}

SOD level was non-significantly $(p>0.05)$ reduced in the untreated group (group 2), and nonsignificantly $(p>0.05)$ increased in the test groups (groups 3,4 , and 5), as well as the standard control (group 6) when compared with the normal control.

\subsubsection{Glutathione Peroxidase (GPx) Activity of Rats Administered with CECDR}

GPx activity in the untreated group showed significant $(p<0.05)$ decrease compared to the normal control, while treatment with CECDR markedly increased GPx concentration in all the test groups. Treatment with the standard drug, silymarin in group 6 also showed significant $(p<0.05)$ increase in the activity of GPx compared to the untreated group.

\subsubsection{Concentration of Malondialdehyde (MDA)}

The concentration of MDA was significantly $(p<0.05)$ increased in the untreated group compared to the normal control, while the treated groups (group 3 and 4) administered $200 \mathrm{mg} / \mathrm{kg}$ and $400 \mathrm{mg} / \mathrm{kg}$ body weight of CECDR showed significant $(p<0.05)$ decrease compared to the untreated group as well as with the group treated with standard drugs, silymarin (group 6).

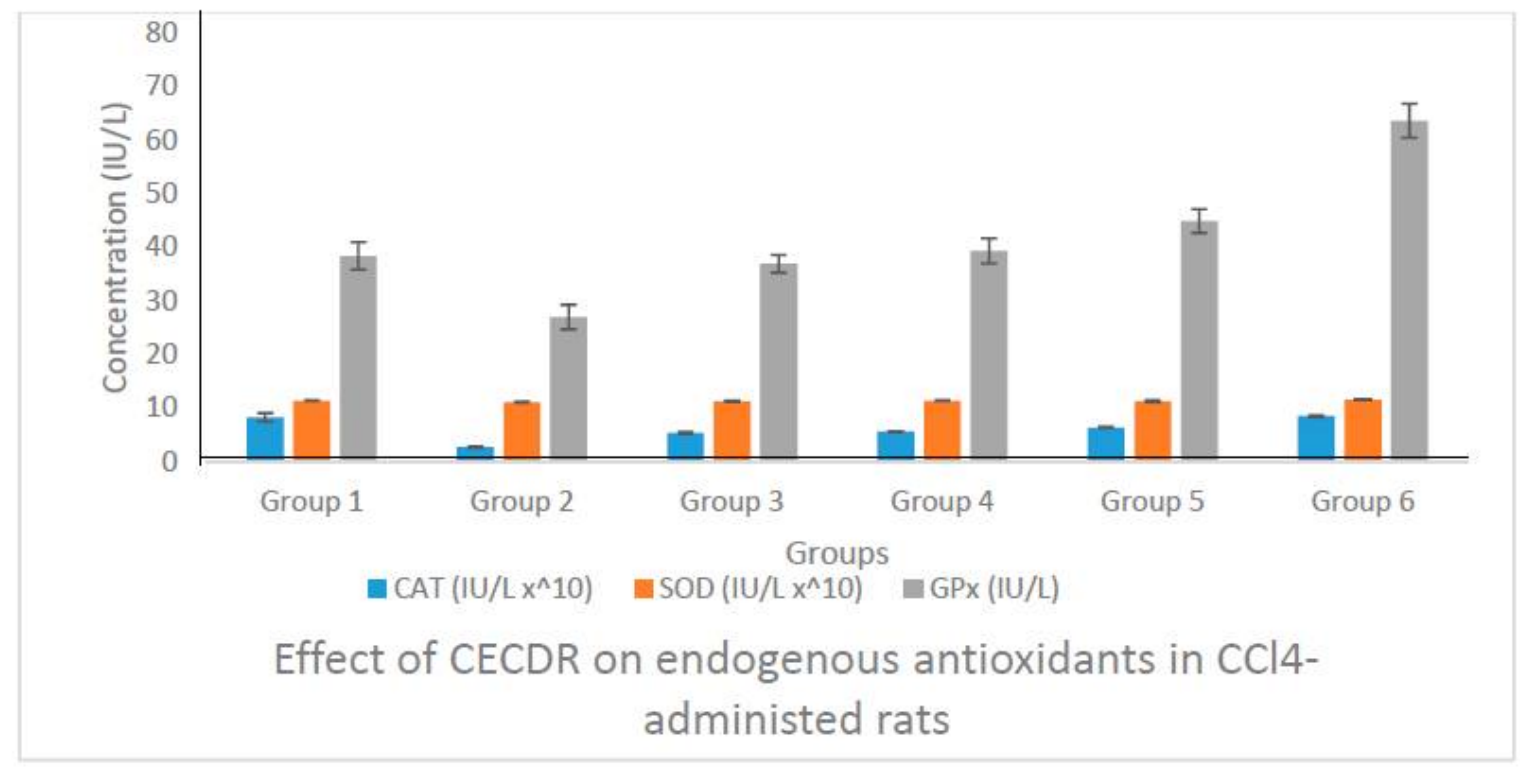

Figure 3. Effect of CECDR on endogenous antioxidants in CCl4-administed rats.

Results are expressed in mean \pm SD $(n=4)$.

Group 1 = Normal control (administered with normal saline)

Group 2 = Experimental control $\left(\mathrm{CCl}_{4}\right.$ induced and untreated $)$

Group $3=\mathrm{CCl}_{4}$ administered and treated with $200 \mathrm{mg} / \mathrm{kg}$ body weight of CECDR

Group $4=\mathrm{CCl}_{4}$ administered and treated with $400 \mathrm{mg} / \mathrm{kg}$ body weight of CECDR

Group $5=\mathrm{CCl}_{4}$ administered and treated with $600 \mathrm{mg} / \mathrm{kg}$ body weight of CECDR 
The 1st International Electronic Conference on Antioxidants in Health and Disease, 1-15 December 2020

Group 6 = Standard control $\left(\mathrm{CCl}_{4}\right.$ administered and treated with $200 \mathrm{mg} / \mathrm{kg}$ body weight of Silymarin)

$\mathrm{CECDR}=$ Chloroform extract of Chasmanthera dependens root

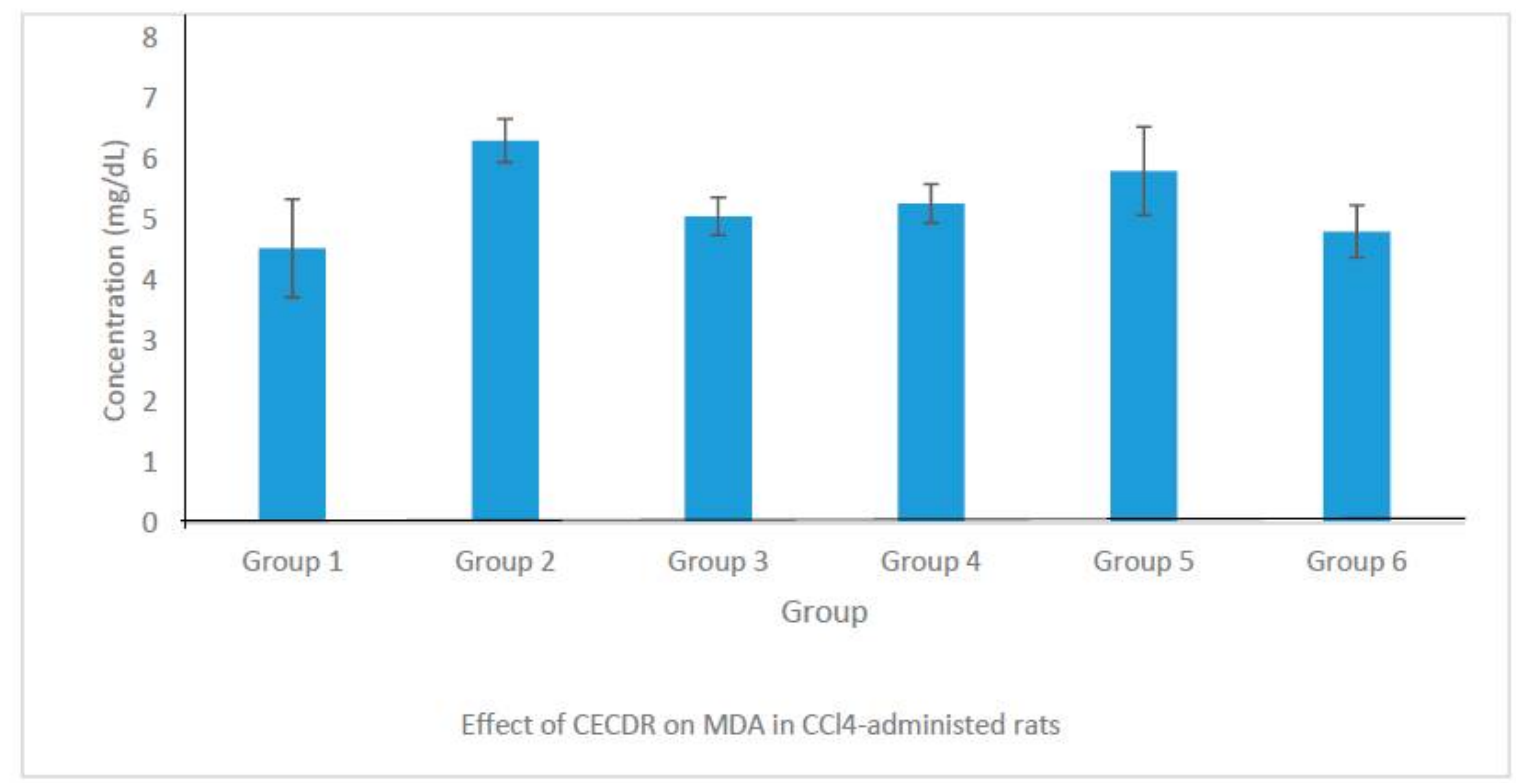

Figure 4. Effect of CECDR on malondialdehyde concentration in CCl4-administed rats.

Results are expressed in mean \pm SD $(n=4)$.

Group 1 = Normal control (administered with normal saline)

Group 2 = Experimental control $\left(\mathrm{CCl}_{4}\right.$ induced and untreated)

Group $3=\mathrm{CCl}_{4}$ administered and treated with $200 \mathrm{mg} / \mathrm{kg}$ body weight of CECDR

Group $4=\mathrm{CCl}_{4}$ administered and treated with $400 \mathrm{mg} / \mathrm{kg}$ body weight of CECDR

Group $5=\mathrm{CCl}_{4}$ administered and treated with $600 \mathrm{mg} / \mathrm{kg}$ body weight of CECDR

Group6 $=$ Standard control $\left(\mathrm{CCl}_{4}\right.$ administered and treated with $200 \mathrm{mg} / \mathrm{kg}$ body weight of Silymarin)

$\mathrm{CECDR}=$ Chloroform extract of Chasmanthera dependens root

\section{Disscusion}

In many regions of the world, traditional medicines are a part of everyday life. (Bussman and Sharon, 2006). In this study, we investigate the antioxidant properties of the chloroform extract of the root of a medicinal plant, Chasmanthera dependens. CECDR showed positive test for the presence of phenols, alkaloids, carbohydrates, flavonoids, terpenes, reducing sugar, tannins and steroids which is in agreement with the findings of Ogbozor and Anosike, (2020). Flavonoids and phenols are known to have free radicals scavenging ability and anti-oxidant property (Sairan et al., 2017). Therefore, these metabolites are believed to be responsible for the observed therapeutic effects of CECDR. The results showed that the DPPH radical scavenging activities of CECDR increase gradually $(p<0.05)$ as the concentration increases. CECDR (EC50 of $-646.67 \mu \mathrm{g} / \mathrm{mL})$ in higher concentration possess higher antioxidant potential compared to the standard ascorbic acid (EC50 of $-10.58 \mu \mathrm{g} / \mathrm{mL}$ ). The strong antioxidant activities of CECDR might be correlated with the high level of phenolics and flavonoids. CECDR having an $\mathrm{EC}_{50}$ of $-58.78 \pm 2.93 \mu \mathrm{g} / \mathrm{mL}$ was found to have higher $\mathrm{H}_{2} \mathrm{O}_{2}$ radical scavenging activity than ascorbic acid (EC50 of $90.06 \mu \mathrm{g} / \mathrm{mL}$ ). At $15.6 \mu \mathrm{g} / \mathrm{mL}$, CECDR had a FRAP of $21.18 \pm 0.15$ $\mu \mathrm{g}$ GAE while at $1000 \mu \mathrm{g} / \mathrm{mL}$, it demonstrated a FRAP of $0.03 \pm 0.00 \mu \mathrm{g}$ GAE. This showed that the Ferric Reducing Antioxidant Power of CECDR increases with decreasing concentration of the extract. The CECDR at the concentrations $15.6 \mu \mathrm{g} / \mathrm{mL}$ and $1000 \mu \mathrm{g} / \mathrm{mL}$ exhibited a Total Antioxidant Capacity 
The 1st International Electronic Conference on Antioxidants in Health and Disease, 1-15 December 2020

(TAC) of $15.22 \pm 7.81 \mu \mathrm{g}$ AAE and $0.03 \pm 0.00 \mu \mathrm{g}$ AAE respectively. This also indicates a significant increase $(p<0.05)$ in TAC with decreasing concentration of the extract.

A significant $(p<0.05)$ reduction in the concentration of endogenous antioxidant enzymes (catalase, superoxide dismutase and glutathione peroxidase) was observed in group 2 due to $\mathrm{CCl}_{4}$ administration without treatment, suggesting that the free radicals generated by $\mathrm{CCl}_{4}$ overwhelmed the endogenous antioxidant enzymes activities. However, treatment with CECDR resulted in significant elevation $(p<0.05)$ elevation across the test groups. This could be attributed to the fact that CECDR is rich in antioxidants which revived and enhanced the activities of the endogenous antioxidant enzymes. Flavonoids, terpenoids and phenolics found in CECDR are important antioxidants that can aid in combating lipid peroxidation and oxidative stress induced by $\mathrm{CCl}_{4}$. $\mathrm{Also}_{\text {, }}$ administration of $\mathrm{CCl}_{4}$ significantly $(p<0.05)$ elevated the concentration of malondialdehyde in group $2\left(\mathrm{CCl}_{4}\right.$-induced and untreated) rats compared to those in group 1 (Normal control). This could be due to lipid peroxidation by the free radical generated by $\mathrm{CCl}_{4}$. The test groups showed a significant $(p<0.05)$ reduction in their malondialdehyde concentration, suggesting that $C$. dependens abated lipid peroxidation.

\section{Conclusions}

In conclusion, the results obtained from this present study shows that the chloroform extract of Chasmanthera dependens have potent antioxidant effect and this can be credited to the antioxidant activities of its constituent phytochemicals such as flavonoids, phenolics, terpenes, which can enhance the activities of endogenous antioxidants.

\section{References}

1. Ogunlesi, M.; Okiei, W.; Ademoye, M.; Osibote, A.E. Analysis of essential oil from the stem of Chasmanthera dependens. J. Nat. Prod. 2009, 3, 47-53.

2. Shrikant, S.S.; Gupta, B.L. Antimicrobial activity of medicinal plants on urinary tract pathogens. Int. J. Pharm. Pharm. 2012, 4, 1.

3. Monon, K.; Karamoko, O.; Goueh, G.; Abuo, O.; Adama, C. Study on ethnopharmacological and phytochemical screening of some plants involved in the treatment of abdominal infection in the department of Kouto (COTE D' IVOIRE). SJAMS 2013, 1, 56-61.

4. Vijaya, L.; Phatak, A.; Chandra, N. Antioxidant and free radical scavenging activity of Hygrophila schulli (Buch.-Ham.) Almeida and Almeida seeds. ABR 2010, 1, 7.

5. Chun-Weng, P.; Sri, N.M.; Halijah, I.; Norhanom, A.W. Antioxidant properties of crude and fractionated extracts of Alpinia mutica rhizomes and their total phenolic content. Afr. J. Pharm. Pharmacol. 2011, 5, 842852.

6. Amoussa, A.M.; Lagnika, L.; Tchatchedre, M.; Laleye, A.; Sanni, A. Acute toxicity and antifungal effects of Acacia ataxacantha (Bark). Int. J. Pharmacogn. Phytochem. Res. 2015, 7, 661-668.

7. Reenu, J.; Azeez, S.; Bhageerathy, C. In vitro antioxidant potential in sequential extracts of curcuma caesia roxb. rhizomes. Indian J. Pharm. Sci. 2015, 77, 41.

8. Kanwal, R.; Arshad, M.; Bibi, Y.; Asif, S.; Khalil, S. Evaluation of Ethnopharmacological and Antioxidant Potential of Zanthoxylum armatum DC. J. Chem. 2015, 2015, 925654.

9. Fanta, Y.; Taiwe, S.G.; Ngatcha, Z.S.; Khan, M.A.; Agbor, G.A.; Ur-Rahman, N.; Ngo, B.E. Quantification of Bioactive compounds and evaluation of the antioxidant activity of Carissa edulis Valh (Apocynaceae) leaves. Sci. World J. 2019, 2019, 7549620.

10. Ozioko, S.C.; Madueke, A.C.; Anosike, A.C. Phytochemical composition and free radical scavenging activity of Cucurbita maxima fruit juice. Res. J. Adv. Sci. 2020, 1, 17-26.

11. Lateef, A.; Ojo, S.A.; Elegbede, J.A.; Azeez, M.A.; Yekeen, T.A.; Akinboro, A. Evaluation of some biosynthesized silver nanoparticles for biomedical applications: Hydrogen peroxide scavenging, anticoagulant and thrombolytic activities. J. Clust. Sci. 2016, 28, 1379-1392.

12. Borokini, T.I.; Lawal, I.O. Traditional medicine practices among the Yoruba people of Nigeria: A historical perspective. J. Med. Plants Stud. 2014, 2, 20-33. 
The 1st International Electronic Conference on Antioxidants in Health and Disease, 1-15 December 2020

13. Use of Tropical Plant Database, UTPD. Chasmanthera dependens. Available online: http://:tropical.theferns.info (accessed on 28 April 2016).

14. Mosango, D.M. Chasmanthera dependens Hochst. Flora 2008, 27, 1844.

15. Wahab, O.M. Ethnomedicinal Antiepileptic plants used in parts of Oyo and Osun States, Nigeria. BRI 2015, $8,77-81$.

16. Onabanjo, A.O.; John, T.A.; Sokale, A.A.; Samuel, O.T. Analgesic and Antiinflammatory Effects of Chasmanthera dependens. Int. J. Pharmacognosy 1991, 29, 24-28, doi:10.3109/13880209109082844.

17. Kola-Mustapha, A.T.; Yohanna, K.A.; Ghazali, Y.O.; Ayotunde, H.T. Design, formulation and evaluation of Chasmanthera dependens Hochst and Chenopodium ambrosioides Linn based gel for its analgesic and antiinflammatory activities. Heliyon 2020, 6, e04894, doi:10.1016/j.heliyon.2020.e04894.

18. Augustine, C.; Anosike, C. Anti-Ulcerogenic Effect of the Chloroform Extract of Chasmanthera dependens on Indomethacin and Aspirin-Induced Ulcer in Rats. J. Nutr. Ecol. Food Res. 2017, 4, 131-137, doi:10.1166/jnef.2017.1164.

19. Quadri, A.L.; Yakubu, M.T. Fertility enhancing activity and toxicity profile of aqueous extract of Chasmanthera dependens roots in male rats. Andrologia 2017, 49, doi:10.1111/and.12775.

20. Ogbozor, C.S.; Anosike, C.A. The Effect of Chloroform Extract of Chasmenthera Dependens on Carbon Tetrachloride (Ccl4) Induced Hepatotoxicity. Glob. Sci. J. 2020, 8. Available online: www.globalscientificjournal.com (accessed on).

21. Abiola, T.S.; Susan, A.O.; Olusegun, B.O. Tannin-Rich Extract of Chasmanthera dependens Stem Potential in Piroxicam-Induced Nephrotoxicity in Adult Male Wistar Rats. Am. J. Mol. Biol. 2020, 10, 29-43, doi:10.4236/ajmb.2020.101003.

22. Lorke, D. A new practical approach to practical acute toxicity testing. Acute Toxicol. 1983, 53, $275-289$.

23. Wallis, T.E. Textbook of Pharmacognosy, 5th ed.; J and A Churchil Ltd.: London, UK, 1967; pp. 81-82.

24. Harborne, J.B. Phytochemical Methods, 11th ed.; Chapman and Hall. New York, USA, 1973.

25. Swain, T. Tannins and Lignins. In Herbivores: Their Interaction with Secondary Plant Metabolites; Rosenthal, G.A., Janzen, D.H., Eds.; Academic Press: New York, NY, USA, 1979; pp. 657-682.

26. Trease, G.E.; Evans, W.C. Pharmacognosy, 12th ed.; Bailliere Tridal: London, UK, 1983.

27. Brunner, J.H. Direct spectrophotometric determination of saponins. Anal. Chem. 1984, 34, 1314-1326.

28. Sofowora, E.A. Medicinal Plants and Traditional Medicine in Africa, 3rd ed.; Spectrum Books Ltd.: Ibadan, Nigeria, 2008; p. 439.

29. Gyamfi, M.A.; Yonamine, M.; Aniya, Y. Free radical scavenging activity of medicinal herbs of Ghana: Thonningia sanguinea on experimentally induced liver injuries. Gen. Pharmacol. 1999, 32, 661-667.

30. Sahreen, S.; Khan, M.R.; Khan, R.A. Evaluation of antioxidant activities of various solvent extracts of Carissa Opaca fruits. Food Chem. 2010, 122, 1205-1211.

31. Benzie, I.F.; Strain, J.J. The ferric reducing ability of plasma (FRAP) as ameasure of "antioxidant power": The FRAP assay. Anal. Biochem. 1996, 239, 70-76.

32. Ruch, R.J.; Cheng, S.J.; Klaunig, J.E. Prevention of cytotoxicity and inhibition of intracellular communication by antioxidant catechins isolated from Chinese green tea. Carcinogenesis 1989, 10, 1003.

33. Garrat DC: The Quantitative Analysis of Drugs; Chapman and Hall: Japan, 1964; pp. 456-458.

34. Paglia, D.E.; Valentine, W.N. Studies on the qualitative and quantitative characterization of erythrocyte glutathione peroxidase. J. Lab. Clin Med. 1967, 70, 158-169.

35. Satoh, K. Serum lipid peroxide in cerebrovascular disorders determined by a new colorimetric method. Clin. Chim. Acta 1978, 90, 37-43.

36. Sarian, M.N.; Ahmed, Q.U.; So'ad, S.Z.M.; Alhassan, A.M.; Murugesu, S.; Perumal, V.; Mohamad, S.N.A.S.; Khatib, A.; Latip, J. Antioxidant and antidiabetic effects of flavonoids: A structure-activity relationship based study. BioMed. Res. Int. 2017, 2017, 8386065.

37. Bussmann, R.W.; Sharon, D. Traditional medicinal plant use in Northern Peru: Tracking two thousand years of healing culture. J. Ethnobiol. Ethnomed. 2006, 2, 47.

Publisher's Note: MDPI stays neutral with regard to jurisdictional claims in published maps and institutional affiliations. 
(C) 2020 by the authors. Submitted for possible open access publication under the terms and conditions of the Creative Commons Attribution (CC BY) license (http://creativecommons.org/licenses/by/4.0/). 